\title{
Historic income versus inflation-adjusted income in the dividend decision
}

\author{
D.P. du Plessis
}

Sanlam Investments, Sanlamhof

\author{
A.A. Archer \\ University of Stellenbosch Business School, Bellville
}

\author{
J.F. Affleck-Graves \\ Graduate School of Business, University of Cape Town, Rondebosch
}

\begin{abstract}
An attempt is made to determine to what extent companies take into account the effects of inflation in formulating their dividend decisions. The research design incorporates a twostage regression approach which permits a determination of the incremental explanatory power of collinear variables. The research findings suggest that dividend decisions are best explained in terms of historic earnings. It therefore appears as if management does not take the effects of inflation into account in formulating dividend policy. This could have serious implications for the survival of a company because it could result in a real dividend cover of less than one.

S. Afr. J. Bus. Mgmt. 1986, 17: 119-124
\end{abstract}

'n Poging word aangewend om te bepaal in watter mate maatskappye die effek van inflasie in ag neem in die formulering van dividendbesluite. Die navorsingsmetodiek omvat ' $n$ tweefase-regressiebenadering, wat die bepaling van die ekstra verduidelikingskrag van saamlynige veranderlikes moontlik maak. Die resultate dui daarop dat dividendbesluite beter verduidelik kan word in terme van historiese verdienste. Dit wil dus lyk asof bestuur nie die effek van inflasie in ag neem in die formulering van dividendbesluite nie. Dit kan ernstige implikasies inhou vir die voortbestaan van 'n maatskappy aangesien dit 'n reële dividenddekking laer as een tot gevolg kan hê.

S.-Afr. Tydskr. Bedryfsl. 1986, 17: 119-124

D.P. du Plessis

Sanlam Invesiments, P.O. Box 1, Sanlamhof,

7532 Republic of South Africa

A.A. Archer*

University of Stellenbosch Business School,

P.O. Box 610, Bellville, 7530 Republic of South Africa

J.F. Ameck-Graves

Graduate School of Business, University of Cape Town,

Private Bag, Rondebosch, 7700 Republic of South Africa

"To whom correspondence should be addressed

Accepted April 1986

\section{Introduction}

The debate as to whether companies should be required to report inflation-adjusted data, and if so, what the nature of the requirements should be, has been the focus of attention for a considerable number of years. This occurred largely because of rising price levels in the seventies and resulted in a number of countries such as the USA and the UK introducing mandatory disclosure of inflation-adjusted income for certain organizations (Bell, 1982).

In the US for example, the Securities and Exchange Commission released Accounting Series Release No 190 (ASR 190) (Securities and Exchange Commission, 1976) which was followed by Statement of Financial Accounting Standards No 33 (SFAS 33) (Financial Accounting Standards Board, 1979) and Statement of Financial Accounting Standards No 82 (SFAS 82) (Financial Accounting Standards Board, 1984). In the UK, the report of the Inflation Accounting Committee under the chairmanship of Sandilands was published (Inflation Accounting Committee, 1975). This had been preceded by an exposure draft, ED 8 (Accounting Standards Committee, 1973) and a provisional statement, PSSAP 7 (Accounting Standards Committee, 1974). In turn, the Sandilands report was followed by ED 18 (Accounting Standards Committee, 1976), the Hyde Guidelines (Accounting Standards Committee, 1977), ED 24 (Accounting Standards Committee, 1979), SSAP 16 (Accounting Standards Committee, 1980), and ED 35 (Accounting Standards Committee, 1984).

In taking the decision to require the reporting of some form of inflation adjustment, the accounting bodies involved implied that such adjustments might provide information useful to present and potential investors, creditors and other users in making rational investment, credit and similar decisions. This, after all, was the primary objective of financial reporting outlined by the Financial Accounting Standards Board in its Statement of Financial Accounting Concepts No 1 (Financial Accounting Standards Board, 1978).

Concurrent with these releases, considerable effort was devoted to analysing the effect of inflation adjustment disclosures on share price behaviour. In the US most of these studies have focused on the information content of ASR 190 and SFAS 33 disclosures. Arbel \& Jaggi (1978); Beaver, Christie \& Griffin (1980); Gheyara \& Boatsman (1980); and Ro (1980) all concluded that inflation adjustment disclosures did not provide information to the market. The fact that the latter three studies, each using a different methodology and different samples, provided consistent 
conclusions provides considerable support for the overall conclusion of no measurable information content (Watts \& Zimmerman, 1980). These conclusions were further substantiated by Beaver, Griffiin \& Landsman (1982) who, using yet another methodology, were unable to find evidence of information content in replacement cost earnings.

In the UK, Brayshaw \& Miro (1985) in a study on market reaction to current cost adjustments, obtained results which were consistent with those obtained in the US studies. Although such market reaction studies do have numerous drawbacks (Hines, 1984), it is difficult to dispute the overall conclusion that inflation adjustments are not a significant source of information for stock market investors.

Such studies, whilst of considerable importance and interest, have paid attention exclusively to the reaction of share prices to the release of inflation-adjusted income measures. They have thus tended to ignore the value of the adjustments both to other users such as creditors and to management. Attention will be focused on the latter group, namely management, and in particular on the impact of inflation on the dividend decision.

The danger of ignoring inflation in the dividend decision has been well documented in the literature (for example, Bar-Yosef \& Lev, 1983; Hale, 1978; and Modigliani \& Cohn, 1979). Specifically it has been stated that one of the effects of rising price levels is the increased replacement cost of fixed assets and the increasing need for working capital necessary to sustain a given volume of business. In theory, inflation profits should therefore not be distributed to shareholders and cash resources should be conserved.

The dividend decision should, at least in part, be influenced by inflation-adjusted income rather than solely by the historic income measure. In particular, quantifying the effects of inflation through a form of inflation accounting could assist in diminishing the danger of a real (i.e. inflationadjusted) dividend cover of less than one. By increasing its historic dividend cover (i.e. reducing the payout ratio), the company will retain relatively more cash in the business, thus assisting to finance the rising needs.

Against this background the question arises: to what extent do companies take into account the effects of inflation in formulating their dividend decisions? The purpose of this study is to submit evidence to this question. This is done by extending the work of Bar-Yosef \& Lev (1983) to determine the ability of inflation-adjusted income to explain changes in dividend over and above the explanation provided by historic income measures.

\section{Data}

The initial set of companies considered in this study consisted of all companies, listed in the industrial section of the Johannesburg Stock Exchange (JSE), with financial years ended in the calender years 1975 to 1982 .

The final sample was produced by applying five sample selection criteria to the initial set of companies. Companies conforming to the criteria enumerated below, ranging from the most to the least restrictive, were excluded for research purposes:

(i) companies with financial years not ending on June 30 for the entire period;

(ii) holding companies that carried no stockholding, and/or where the major investment was represented by another sample constituent;

(iii) companies that experienced structural changes, including those of which the listings were shifted from the industrial to other sections of the JSE;

(iv) companies for which reasonable estimates of inflationadjusted data could not readily be made; and

(v) companies of which the listings were suspended for excessively long periods.

The first requirement resulted in the exclusion of a considerable proportion of the companies. June 30 ars chosen as it proved to be the most common reporting date for those companies who had maintained the same financial year over the entire period.

Application of the sample selection criteria produced a sample of 59 companies.

The analysis focused upon two informational variables i.e. the annual change in historic income and the annua change in inflation-adjusted income, and their relationshi to the annual change in dividend. These variables an discussed in turn in the following paragraphs.

\section{Historic income}

Historic income was for the purpose of this study defined a earnings available for ordinary shareholders, based on consolidated net income for the financial period, after ordinary and foreign taxation, and after deducting outside shareholders' interests and preference dividends, but before extraordinary and abnormal items.

Historic income for a group of companies was therefore based on operating profits attributable to members of the holding company. Deferred taxation was excluded from the calculation in an attempt to avoid possible distortions being introduced as a result of extreme fluctuations in this taxation component. Where the earnings of associated companies were included in a company's income statement, the historic income was based on profits exclusive of associated com panies' results.

The annual change in historic income was formulated as follows.

$\mathrm{HC}_{i, t}=\frac{\mathrm{HI}_{i, t}-\mathrm{HI}_{i, t-1}}{\frac{1}{3}\left(\mathrm{NAV}_{i, t}+\mathrm{NAV}_{i, t-1}+\mathrm{NAV}_{i, t-2}\right)}$

where $\mathrm{HC}_{i, t}=$ relative change in historic income of company $i$ in period $t ; \mathrm{HI}_{i, t}=$ historic income of company $i$ in period;; and $\mathrm{NAV}_{i, t}=$ net asset value of company $i$ at the end of period $t$.

Net asset value was computed by adding all the assets (excluding intangibles), and then subtracting all liabilities, preference share capital, outside shareholders' interests, deferred taxation, and revaluation surpluses. Similar deflators were used by Bar-Yosef \& Lev (1983: 43) and Morris \& McDonald (1982: 388).

\section{Inflation-adjusted income}

Inflation-adjusted income was for the purpose of this study defined as historic income (see definition above) adjusted for the effects of changing price levels, in accordance with the recommendations of Guideline AC 201 (Accounting Practices Committee, 1978). Guideline AC 201 follows the Hyde Guidelines (Accounting Standards Committee, 1977) in that it requires three adjustments to be made, namely: (1) additional depreciation on fixed assets; (2) stock adjustment; and (3) gearing adjustment. In addition, the portion of the inflation-adjustment accruing to outside shareholders interests was taken into consideration in arriving at the estimate for inflation-adjusted income. If price levels did nol 
change, inflation-adjusted income and historic income would, of course, have been identical.

It should be noted that only a few of the companies listed on the JSE have experimented with the recommendations of AC 201. Therefore, all inflation adjustments were calculated using the inflation accounting model of the University of Stellenbosch Business School (Archer, 1980: 94-141). In order to facilitate uniformity in the adjustment procedure, the few companies which published inflation-adjusted data were excluded.

The annual change in inflation-adjusted income was formulated as follows.

$$
\mathrm{RC}_{i, t}=\frac{\mathrm{RI}_{i, t}-\mathrm{RI}_{i, t-1}}{\frac{1}{3}\left(\mathrm{NAV}_{i, t}+\mathrm{NAV}_{i, t-1}+\mathrm{NAV}_{i, t-2}\right)}
$$

where $\mathrm{RC}_{i, t}=$ relative change in inflation-adjusted income of company $i$ in period $t$; and $\mathrm{RI}_{i, t}=$ inflation-adjusted income of company $i$ in period $t$. All other symbols are as described before.

\section{Dividend}

Dividend was for the purpose of this study defined as the sum of all ordinary dividends declared in respect of a particular financial year.

The annual change in dividend was formulated as follows.

$$
\mathrm{DC}_{i, t}=\frac{\mathrm{TD}_{i, t}-\mathrm{TD}_{i, t-1}}{\frac{1}{3}\left(\mathrm{NAV}_{i, t}+\mathrm{NAV}_{i, t-1}+\mathrm{NAV}_{i, t-2}\right)}
$$

where $\mathrm{DC}_{i, t}=$ relative change in dividend of company $i$ in period $t$; and $\mathrm{TD}_{i, t}=$ total dividend paid by company $i$ in period $t$. All other symbols are as described before.

This annual change in dividend was used as the dependent variable in the two-stage regression analysis described below.

\section{Research methodology}

From an informational perspective the central issue in this study revolves around the following two questions:

(i) given historic income figures, do inflation-adjusted income figures significantly increase the explanation of changes in dividend?; and

(ii) given inflation-adjusted income figures, do historic income figures significantly increase the explanation of changes in dividend?

Accordingly, these are the two hypotheses which will be addressed.

It is important to note that the two earnings variables are not necessarily mutually exclusive regarding their explanatory power. Both historic income and inflation-adjusted income share common factors that could explain cross-sectional variation in dividend changes. The level of explanatory power provided by knowledge of more than one variable must therefore be compared with the explanatory power provided by knowledge of only one of the variables.

To examine this issue, two-stage regression analyses were conducted. The approach adopted was similar to that employed by Bar-Yosef \& Lev (1983) and Beaver, Griffin \& Landsman (1982) and consisted of conducting regressions across all company-year observations. This pooled crosssectional approach was adopted for the following reasons.

(i) When the independent variables in a regression are correlated amone themselves. intercorrelation or multi- collinearity is said to exint among them. The presence of multicollinearity makes the interpretation of results difficult and misteading. In particular, the incremental explanatory power of each informational variable becomes blurred. Incorporating several earnings measures in one regression equation as independent variables, would clearly result in multicollinearity. The two-stage regression approach, however, permits the determination of the incremental explanatory power of collinear variables.

(ii) The eamings variables are not treated as being mutually exclusive.

(iii) The magnitude as well as the sign of the earnings variables are incorporated.

\section{The incremental explanatory power of inflation-adjusted income}

This section deals with an examination of the first hypothesis, namely that inflation-adjusted income does not provide additional explanatory power over that provided by historic income. The methodology employed is briefly summarized below.

(i) The annual change in inflation-adjusted income, RC, was regressed on the annual change in historic income, $\mathrm{HC}$, to obtain a residual, $Z$, which is by construction uncorrelated with $\mathrm{HC}$.

$$
\mathrm{RC}_{i t}=\alpha+\beta \mathrm{HC}_{i, t}+Z_{i, t}
$$

where $\mathrm{RC}_{i, t}=$ change in inflation-adjusted income of company $i$ in period $t ; \mathrm{HC}_{i . t}=$ change in historic income of company $i$ in period $t ; Z_{i, t}=$ a random disturbance (or residual) term particular to company $i$ in period $t$; and $\alpha, \beta=$ regression parameters.

The ordinary least squares estimate of $\beta$ was 0,97 ( $t$ value of 74,07$)$. The value of the $R^{2}$ statistic was 0,94 which is significant at the $1 \%$ level. It can therefore be concluded that a significant proportion of the variability in inflation-adjusted income can also be associated with the historic income figure.

(ii) The annual change in dividend, DC, was then regressed on $\mathrm{HC}$ and $Z$.

$\mathrm{DC}_{i, t}=\alpha+\beta_{1} \mathrm{HC}_{i, t}+\beta_{2} Z_{i, t}+U_{i, t}$

where $\mathrm{DC}_{i, t}=$ change in dividend of company $i$ in period $t$; and $U_{i, t}=$ a random disturbance term particular to company $i$ in period $t$. All other symbols are as described before.

If $\mathrm{RC}$ possesses explanatory power not provided by $\mathrm{HC}$, the regression coefficient, $\beta_{2}$, on the residual, $Z$, should be different from zero. The null hypothesis therefore states that the regression coefficient, $\beta_{2}$, in the population is not different from zero. This hypothesis was tested using the $t$ test.

Results for the second-stage regression are summarized in Table 1. It can be seen that the $\beta_{2}$ coefficient is insignificant at the $5 \%$ level. One is therefore unable to reject the null hypothesis and hence cannot conclude that inflation-adjusted income figures provide explanatory power of dividend changes beyond that provided by the historic figures.

\section{The incremental explanatory power of historic income}

It could perhaps be argued that the former procedure is a rather severe test to impose on inflation-adjusted income. As shown in the first-stage regression. RC and $\mathrm{HC}$ are highly 
Table 1 Incremental information content of inflationadjusted income: Summary of results for second-stage regressions

\begin{tabular}{lc}
\hline$\beta_{1}$ & 0,15 \\
$t$ value & $11,43^{\mathrm{a}}$ \\
$\beta_{2}$ & $(0,06)$ \\
$t$ value & $(1,09)$ \\
$R^{2}$ & 0,29 \\
Number of companies & 53 \\
Number of company-year observations & 328 \\
\hline
\end{tabular}

- Denotes significance at the $5 \%$ level.

correlated. It is therefore not unreasonable to believe that the two variables possess a considerable amount of common explanatory power with respect to changes in dividend (i.e. the informational variables are not mutually exclusive). In this section the two-stage model was therefore reversed and run in the opposite direction.

The procedure employed was as follows.

(i) $\mathrm{HC}$ was regressed on $\mathrm{RC}$ to obtain a residual, $Z$, which is by construction uncorrelated with RC.

$\mathrm{HC}_{i, t}=\alpha+\beta \mathrm{RC}_{i, t}+Z_{i, t}$

where all the symbols are as described before.

This regression yielded a $\beta$ estimate of 0,97 ( $t$ value of $74,07)$. Obviously, the $R^{2}$ statistic is once again 0,94 which is significant at the $1 \%$ level.

(ii) $\mathrm{DC}$ was then regressed on $\mathrm{RC}$ and $Z$.

$\mathrm{DC}_{i, \mathrm{r}}=\alpha+\beta_{1} \mathrm{RC}_{i, t}+\beta_{2} Z_{i, t}+U_{i, t}$

where all the symbols are as described before.

If $\mathrm{HC}$ possesses explanatory power not provided by $\mathrm{RC}$, the regression coefficient, $\beta_{2}$, on the residual, $Z$, should be different from zero. The null hypothesis therefore states that the regression coefficient, $\beta_{2}$, in the population is not different from zero. Once again, the hypothesis was tested using the $t$ test.

Results for the second-stage regression are summarized in Table 2. Analysis of the results indicates that the $\beta_{2}$ coefficient was significantly different from zero at conventional levels. One can therefore conclude that historic income figures do possess explanatory power beyond that provided by inflation-adjusted figures.

The results presented in the previous two sections, suggest

Table 2 Incremental information content of historic income: Summary of results for second-stage regressions

\begin{tabular}{lr}
\hline$\beta_{1}$ & 0,14 \\
$t$ value & $10,85^{\mathrm{a}}$ \\
$\beta_{2}$ & 0,20 \\
$t$ value & $3,76^{\mathrm{a}}$ \\
$\boldsymbol{R}^{2}$ & 0,29 \\
Number of companies & 53 \\
Number of company-year observations & 328 \\
\hline Denotes significance at the 5\% level &
\end{tabular}

- Denotes significance at the $5 \%$ level. that to some extent the two sets of figures do act substitutes for one another. The value of the $R^{2}$ statistic in the first stage regression was 0,94 , indicating that $94 \%$ of the variability in one income measure can be explained by the variability in the other income measure. The results of the second-stage regression, however, indicate that only in the case of the historic income does the remaining variation contribute significantly to an explanation of dividend changes.

\section{The effect of inflation}

Both Beaver, Christie \& Griffin (1980: 145) and Gheyara \& Boatsman (1980: 114) structured their studies on the supposition that information content was more interesting for companies affected to a greater extent by inflation. Because the results presented in the previous two sections were averages of the entire sample of 59 companies, it is possible that the significance of the inflation-adjusted figures was dissipated by the presence of several companies relatively unaffected by inflation. It was therefore decided to repeat the analysis after segmenting the sample into three subgroups on the following basis.

First, the companies were ranked in terms of the impact of inflation on their historic income. This impact was measured by the absolute difference between a company's historic income and inflation-adjusted income. In order to obtain a relative measure, this difference was scaled by the average net asset value on an historic cost basis.

The inflation impact was thus formulated as follows.

$$
\mathrm{II}_{i, t}=\frac{\mathrm{RI}_{i, t}-\mathrm{HI}_{i, t}}{\frac{1}{2}\left(\mathrm{NAV}_{i, t}+\mathrm{NAV}_{i, t-1}\right)}
$$

where $\mathrm{II}_{i, t}=$ inflation impact of company $i$ in period $t ; \mathrm{RI}_{i, t}=$ inflation-adjusted income of company $i$ in period $t ; \mathrm{HI}_{i, t}=$ historic income of company $i$ in period $t$; and $\mathrm{NAV}_{i, t}=$ net asset value of company $i$ at the end of period $t$.

The inflation impact was expressed in terms of an average figure, calculated as the arithmetic average of the series of annual figures over the duration of the research period. An average measure was used in an attempt to smooth possible wide fluctuations in the annual inflation impact as a result of factors pertaining to the economy.

The top end of the ranking comprised those companies suffering from severe inflationary pressure (i.e. companies where inflation had a large impact on historic income), whereas the tail end was made up of those that had been relatively successful in hedging inflation (i.e. companies where inflation had a small impact on historic income).

Finally, the average inflation impact figures were used to partition the ranked companies into three approximately equal-sized subgroups. These groups were labelled from $A$ to $C$, with the companies in group $\mathrm{A}$ being the most affected, and companies in group $C$ being the least affected by the impact of inflation on their historic income.

For the high inflation impact group (i.e. group A) the first-stage regression resulted in an $R^{2}$ value of 0,87 , once again indicating a high degree of co-movement between historic and inflation-adjusted income figures.

Results for the second-stage regression are summarized in Table 3 (columns 1 and 2 ). The results are essentially the same as those presented in Tables 1 and 2 . The inflationadjusted income figure does not provide any significant additional explanation of changes in dividends other than 
Table3 Incremental information content of inflationadjusted and historic income: Summary of results for second-stage regressions

\begin{tabular}{lccccc}
\hline & \multicolumn{2}{c}{ Group A } & & \multicolumn{2}{c}{ Group C } \\
\cline { 2 - 3 } \cline { 5 - 6 } & $\begin{array}{c}\text { Inflation- } \\
\text { adjusted } \\
\text { income } \\
(1)\end{array}$ & $\begin{array}{c}\text { Historic } \\
\text { income } \\
(2)\end{array}$ & & $\begin{array}{c}\text { Inflation- } \\
\text { adjusted } \\
\text { income } \\
(3)\end{array}$ & $\begin{array}{c}\text { Historic } \\
\text { income } \\
(4)\end{array}$ \\
\hline$\beta_{1}$ & 0,14 & 0,13 & & 0,16 & 0,15 \\
$t$ value & $8,40^{\mathrm{a}}$ & $7,80^{\mathrm{a}}$ & & $8,15^{\mathrm{a}}$ & $7,94^{\mathrm{a}}$ \\
$\beta_{2}$ & $(0,01)$ & 0,15 & & $(0,01)$ & 0,16 \\
$t$ value & $(0,13)$ & $3,11^{\mathrm{a}}$ & & $(0,01)$ & $1,81^{\mathrm{b}}$ \\
$R^{2}$ & 0,37 & 0,37 & & 0,44 & 0,44 \\
$\begin{array}{l}\text { Number of } \\
\text { companies }\end{array}$ & 20 & 20 & & 15 & 15 \\
$\begin{array}{l}\text { Number of } \\
\text { company- }\end{array}$ & & & & & \\
year ob- & & & & & \\
servations & 123 & 123 & 88 & 88 \\
\hline
\end{tabular}

Denotes significance at the $5 \%$ level.

- Denotes significance at the $10 \%$ level.

that already provided by the historic income figure. However, once again, the historic income figure does appear to possess additional explanatory power over and above that provided by the inflation-adjusted income figure. Thus, for the high inflation impact group it would appear that the two income measures do not provide identical information.

For the low inflation impact group (i.e. group C), the firststage regression results yielded an $R^{2}$ value of 0,95 which indicates that $95 \%$ of the variation in the one income measure can be explained by the other income measure. This is higher than the 0,87 for the high inflation impact group, but is to be expected as one would anticipate a higher degree of co-movement between the two sets of income figures for the lower inflation impact group.

Results for the second-stage regression are summarized in Table 3 (columns 3 and 4) and are similar to those obtained from the high inflation impact group. Once again the $\beta_{2}$ coefficient is insignificant in the case of inflation-adjusted income figures, but significant (at 10\% level) in the case of historic income figures.

In concluding this section, it can be said that the results obtained suggest that the inflation-adjusted income figures do not significantly improve the ability of historic earnings to explain dividend changes. The basic finding is therefore consistent with the hypothesis that no additional explanatory power is provided by inflation-adjusted figures, given knowledge of historic income. Historic income, however, does provide explanatory power beyond that provided by inflation-adjusted income

In addition, it is worth noting that in all cases the $\beta_{1}$ coefficient in the second-stage regressions is always highly significant. This confirms that the income figure (whether on an historic or inflation-adjusted basis) does significantly explain some of the variation in dividends.

The entire statistical analysis was duplicated for a holdout sample. The second (i.e. holdout) sample was chosen using the same criteria as applied to the initial set of companies, with the exception of the first criterion which was amended to include only companies having a financial year ended on
December 31 for the entire period. In total 29 companies qualified for inclusion in the holdout sample.

The results obtained for the holdout sample (i.e. December year-end companies) were similar to that obtained for the sample (i.e. June year-end companies). Hence the conclusions drawn can be considered to be valid for all companies during the period under study.

\section{Conclusions}

The research findings suggest, somewhat surprisingly, that even after a decade of relatively high rates of inflation, and several years since the publication of a guideline recommending an inflation accounting procedure, dividend decisions are still best explained in terms of historic earnings. The empirical results thus support the findings of an earlier study which found that a rather small percentage of companies employ a form of inflation accounting for internal purposes (Archer, 1980: 183). It therefore appears as if management does not take the effects of inflation into account in formulating dividend policy. This is the same conclusion as that reached by Bar-Yosef \& Lev (1983) in a study of US companies and therefore offers to be a general phenomenon rather than a country-specific result. In addition, the methodology used in this study was different from that used by Bar-Yosef \& Lev and is thus unlikely to be due to methodological deficiencies.

The reason why managers appear to ignore inflation in making their dividend decisions is not easy to explain and we can only, with the assistance of other authors, offer some tentative suggestions.

First, a study conducted in England concluded that inflation-adjusted income was more volatile than historic income (Ross, 1980: 94). This was confirmed by a local study carried out by Archer (1980: 248). It has been argued that such a widely fluctuating figure cannot be used to assist managers in decisions concerning an inherently smooth variable such as dividends. It should, however, be borne in mind that the very reason for the volatility in inflationadjusted earnings can perhaps be ascribed to the fact that management takes decisions based on historic figures. Archer (1980: 249), for example, suggested that if more companies adopted a system of inflation accounting one might expect the historic variable to be the more volatile in a few years' time.

Secondly, it is possible that even during periods of relatively high rates of inflation, present changes in inflation-adjusted earnings do not signal changes in future cash flows to management, hence no adjustment in dividends commensurate with those earnings changes deemed necessary (BarYosef \& Lev, 1983: 46).

Thirdly, the measurement error associated with the inflation adjustments recommended in Guideline AC 201 could be so serious as to render the resulting data unreliable.

Finally, it may be that the advantage of inflation-adjusted data in the dividend decision will only become apparent over the long term, as the effects of inflation on year-to-year financial results accumulate.

Financial theory clearly indicates that a company cannot maintain a real dividend cover of less than one ad infinitum. Thus, the inflation-adjusted income figure must ultimately form the basis of any long-term dividend policy decision. This article shows that this does not appear to be current management practice. Tentative reasons why this has occurred are offered, but further research is needed to provide a final answer. 


\section{Acknowiedgements}

The authors wish to acknowledge financial support by the Human Sciences Research Council, and programming assistance by Mr W.R. Gevers of the University of Stellenbosch Business School.

\section{References}

Acoounting Practices Committee. 1978. Guideline on Disclosure of Effects of Changing Prices on Financial Results No AC 201 (formerly No 4.003), Johannesburg: National Council of Chartered Accountants (SA). 6p.

Accounting Standards Committee. 1973. Accounting for the Changes in the Purchasing Power of Money, Exposure Draft 8, January.

Accounting Standards Committee. 1974. Accounting for the Changes in the Purchasing Power of Money, Provisional Statement of Standard Accounting Practice 7, May.

Accounting Standards Committee. 1976. Current Cost Accounting, Exposure Draft 18, November.

Accounting Standards Committee. 1977. Inflation Accounting - an Interim Recommendation (The Hyde Guidelines), November.

Accounting Standards Committee. 1979. Current Cost Accounting, Exposure Draft 24, April.

Accounting Standards Committee. 1980. Current Cost Accounting, Statement of Standard Accounting Practice 16, March.

Accounting Standards Committee. 1984. Accounting for the Effects of Changing Prices, Exposure Draft 35, July.

Arbel, A. \& Jaggi, B. 1978. Impact of Replacement Cost Disclosures on Investors' Decisions in the United States. Int. J. Acc. Education Res., Fall, 71-82.

Archer, A.A. 1980. The Relevance of Guideline 4.003 (of the SA Institute of Chartered Accountants) for Financing and Dividend Policy Decisions. Unpublished doctoral dissertation, University of Stellenbosch. 445p.

Bar-Yosef, S. \& Lev, B. 1983. Historical Cost Earnings versus Inflation-adjusted Earnings in the Dividend Decision. Financ Analysts J., March-April, 41-50.

Beaver, W.H., Christie, A.A. \& Griffin, P.A. 1980. The Information Content of SEC Accounting Series Release No 190. J. Acc. Econ. August, 131-157.

Beaver, W.H., Griffin, P.A. \& Landsman, W.R. 1982. The Incremental
Information Content of Replacement Cost Earnings. J. Acc. Econ., July, 15-39.

Bell, P.W. 1982. Some Thoughts on 'Inflation Accounting' in Great Britain and the United States. Accountants' Magazine, October, 356-358, 373.

Brayshaw, R.E. \& Miro, A.R.O. 1985. The Information Content of Inflation-adjusted Financial Statements. J. Bus. Fin. Acc., Summer, 249-261.

Financial Accounting Standards Board. 1978. Objectives of Financial Reporting by Business Enterprises, Statement of Financial Accounting Concepts No 1, 1978.

Financial Accounting Standards Board. 1979. Financial Reporting and Changing Prices, Statement of Financial Accounting Standards No 33, September.

Financial Accounting Standards Board. 1984. Financial Reporting and Changing Prices: Elimination of Certain Disclosures, Statement of Financial Accounting Standards No 82, November.

Gheyara, K. \& Boatsman, J. 1980. Market Reaction to the 1976 Replacement Cost Disclosures. J. Acc. Econ., August, 107-125.

Hale, D. 1978. Inflation Accounting and Public Policy Around the World. Financ. Analysts J., November-December, 28-40.

Hines, R.D. 1984. The Implications of Stock Market Reaction (Nonreaction) for Financial Accounting Standard Setting. Acc. Bus. Res., Winter, 3-14.

Inflation Accounting Committee. 1975. Report of the Inflation Accounting Committee (Chairman F.E.P. Sandilands Esq., O.B.E.) London: Her Majesty's Stationery Office. 364p.

Modigliani, F. \& Cohn, R.A. 1979. Inflation, Rational Valuation and the Market. Financ. Analysts J., March-April, 24-44.

Morris, M.H. \& McDonald, B. 1982. Asset Pricing and Financial Reporting with Changing Prices. J. Bus. Fin. Acc., Autumn, 383395.

Ro, B.T. 1980. The Adjustment of Security Returns to the Disclosure of Replacement Cost Accounting Information. J. Acc. Econ., August, 159-189.

Ross, D. 1980. The Advantages of CCA for Decision-makers. Accountancy, August, 92-94.

Securities and Exchange Commission. 1976. Accounting Series Release No 190, March.

Watts, R.L. \& Zimmerman, J.L. 1980. On the Irrelevance of Replacement Cost Disclosures for Security Prices. J. Acc. Econ. August, 95-106. 